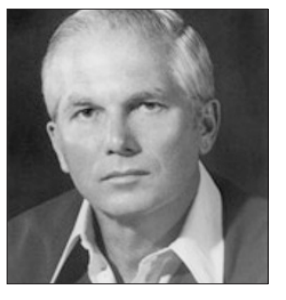

\title{
Frank J. Dixon
}

\section{0-2008}

\section{Michael B A Oldstone}

Frank J. Dixon, an exceptional scientist who merged the fields of experimental pathology and immunology to develop immunopathology as a coherent discipline, died 8 February 2008 in his La Jolla home from complications of valvular heart disease. He was 87.

Frank J. Dixon was born in St. Paul, Minnesota, on 9 March 1920 and entered the University of Minnesota in 1937. After 2 years of undergraduate study, he entered medical school there, and, by 1943, he had received his BS, MS and MD degrees. From 1943 to 1946 he served in the medical core of the Marines in the Pacific Theater. Thereafter he spent 2 years as a research assistant at Harvard Medical School's Department of Pathology and was an instructor at the Washington University School of Medicine from 1948 to 1951. In 1951, at the age of 30, he became Chair of the Department of Pathology at the University of Pittsburgh, a position he held for 10 years before heading west to La Jolla, California, to found the Department of Experimental Pathology and a research institute at the Scripps Clinic.

Devoting the initial phase of his career toward understanding the nature of antibody formation and antigen-antibody relationships and interactions, Dixon developed techniques to tag proteins and other molecules with radioactive iodine, a procedure still in use today. This method enabled researchers to map and follow the progress of such molecules through the body to their final location, where their concentrations could be measured. As a result, such antigen-antibody immune complexes and the inflammatory mediators they activated could be identified and linked with the diseases they caused.

Using experimental animal models, Dixon was able to show specific antigen-antibody complexes concentrated at sites of tissue damage, especially in the kidneys, blood vessels, heart and joints, and the attraction to those sites of inflammatory mediators such as complement. He extended those findings in laboratory animals to humans with kidney and heart disease and lupus erythematosus. With his students, he expanded that inquiry into antibody-mediated injury to membranes and to chronic persistent viral infection caused by Aleutian disease of mink, lymphocytic choriomeningitis and retroviruses. Studies of the last two pathogens indicated for the first time that a host that becomes persistently infected congenitally or in utero is not immunologically tolerant to that agent. Instead, the infected host mounts an antiviral immune response at the B cell level that results in the formation of virus-antibody immune complexes, leading to immune-complex disease in the renal glomeruli and blood vessels later in life.

The fruits of his labor were recognized early when the American Association for the Advancement of Science named him the nation's leading medical researcher under the age of 35 in 1951. In 1975 he received the Albert Lasker Medical Research Award (the American 'Nobel prize') for his pioneering work defining the immunological basis of tissue disease, especially renal and vascular injury.

Yet perhaps his most remarkable accomplishment was in 1961 when he deliberately and in the face of considerable risk created his own

$$
\begin{aligned}
& \text { His vision was to concentrate whole, } \\
& \text { independent laboratories researching } \\
& \text { experimental models of human disease. }
\end{aligned}
$$

research institution. His vision was to concentrate whole, independent laboratories researching experimental models of human disease. This goal led Dixon to seek a place where he and his faculty could pursue research undisturbed by the necessary university business of administration, teaching and patient care. It was in this climate that Dixon and four other experimental pathologists from the University of Pittsburgh Medical School moved to the then remote hamlet of La Jolla, where they accepted an invitation from a small and financially limited Scripps medical clinic that offered no institutional barriers to full-time research, provided it paid its own way. This move preceded by several years the building of the Salk Institute and the University of California San Diego in La Jolla. Beginning with five staff members and seven postdoctoral fellows, Dixon's vision evolved into one of the world's premiere research institutions, which launched and enhanced the careers of many prominent immunologists, virologists and experimentalists.

The foundation for today's research institute built during the 25 years of Dixon's directorship from 1961 to 1986 underlies its continuing expansion and commitment to excellence under the present leadership of his former postdoctoral fellow, Richard Lerner.

Frank Dixon is survived by his wife of 62 years, Marion; their three children, Janet, Frank Jr. and Michael; four grandchildren; over 78 postdoctoral fellows whom he personally mentored; and the institution to which he gave birth. 